\title{
JEKK \\ Potensi Kombinasi Adenosine Diphosphate-Ribosylation Like 4c Antisense Oligonuclotide-1316 dengan Polyamidoamine Dendrimer Generasi 4-Anti Surfactant Protein B sebagai Terapi Adenokarsinoma Paru
}

\author{
Adrian Wiryanata Gorintha*, Andrea Ivena*, Putu Aprilyanti Aristadewi*, Agung Wiwiek Indrayani** \\ *Program Studi Sarjana Kedokteran dan Profesi Dokter Fakultas Kedokteran, Universitas Udayana, \\ *** Departemen Farmakologi dan Terapi Fakultas Kedokteran, Universitas Udayana.
}

\begin{abstract}
Background: Lung cancer is a disease of the respiratory system that gets special attention because the World Health Organization (WHO) has reported that in 2018, lung cancer was the cancer with the highest number of morbidity and mortality rate in the world. There are several types of lung cancer, one of which is adenocarcinoma, which accounts for about $40 \%$ of all lung cancers. In its management, cancer cells often develop resistance to EGFR TKI drugs while Cisplatin and Crizotinib have quite dangerous side effects, namely bradycardia to cardiotoxicity.

Methods: The method used is a literature review with literature sources in the form of relevant article from search engine such as Pubmed and Google Scholar that contain keyword "ARL4C ASO-1316", "lung adenocarcinoma", "PAMAM Dendrimer Generasi 4" and "anti SFTPB antibody".

Result: The ability of ARL4C ASO-1316 in inhibiting the division and migration of lung adenocarcinoma cells has been proven in vivo and in vitro so that it can provide hope in the form of new modalities in the treatment of lung adenocarcinoma. In addition, the combination with the PAMAM Dendrimer G4-Anti SFTPB carrier can increase the ability to deliver ARL4C ASO-1316 to reach target tissues rapidly and can provide maximum effect in the treatment of lung adenocarcinoma. Conclusion: Adenosine diphosphate-ribosylation like $4 \mathrm{c}$ antisense oligonuclotide-1316 with polyamidoamine dendrimer generation 4-anti surfactant protein b should provide novel approaches and new insights for lung adenocarcinoma.
\end{abstract}

Keywords: ARL4C ASO-1316; Lung adenocarcinoma; PAMAM dendrimer G4-anti SFTPB antibody. 


\section{Pendahuluan}

Kanker paru merupakan salah satu dari lima penyakit sistem respirasi yang mendapatkan perhatian khusus karena tingginya angka morbiditas dan mortalitas akibat penyakit ini. World Health Organization (WHO) melaporkan bahwa kanker paru merupakan kanker dengan jumlah pengidap dan tingkat kematian tertinggi di dunia pada tahun 2018. ${ }^{1,2}$ Sementara itu, data dari GLOBOCAN 2018 menunjukkan bahwa kanker paru merupakan kanker terbanyak ketiga setelah kanker payudara dan kanker leher rahim, serta kanker dengan tingkat kematian tertinggi di Indonesia. ${ }^{3}$ Kanker paru dapat menyebabkan efusi pleura, sindrom vena cava superior, hemoptisis, obstruksi jalan napas, dan metastasis ke otak, tulang, hati, atau organ lain. ${ }^{4}$

Terdapat beberapa faktor yang dapat menyebabkan kanker paru di antaranya adalah kebiasaan merokok yang merupakan risiko utama, kontak dengan polusi udara, dan mutasi genetik. Namun, saat ini metode deteksi dini kanker paru belum maksimal sehingga masih berfokus pada upaya pengobatan kanker paru. 5,6

Berdasarkan manajemen terapinya, kanker paru terbagi dalam dua variasi yakni Non small cell lung cancer (NSCLC) dan Small cell lung cancer (SCLC). Non small cell lung cancer terdiri dari beberapa jenis kanker di antaranya Adenokarsinoma, Squamous cell carcinoma, dan Large-cell carcinoma. Sekitar $40 \%$ dari keseluruhan kanker paru merupakan jenis adenokarsinoma, lebih lanjut lagi adenokarsinoma juga merupakan jenis kanker paru yang paling banyak terdiagnosis pada pasien dengan riwayat tidak merokok. ${ }^{7,8,9,10}$

Adenokarsinoma merupakan kanker yang dimulai dari sel glandular pada bronkiolus paru manusia. Pengobatan adenokarsinoma saat ini berfokus pada penggunaan golongan Epidermal Growth Factor Receptor Tyrosine Kinase Inhibitor (EGFR TKI), Cisplatin dan Crizotinib. Meskipun demikian, sel kanker seringkali mengembangkan resistensi terhadap obat golongan EGFR TKI sementara Cisplatin dan Crizotinib memiliki efek samping yang cukup berbahaya yakni kejadian nephrotoxicity (20$30 \%$ ) dan cardiotoxicity (3-20\%) pada pemakaian Cisplatin, serta pneumonitis dan bradikardia pada pemakaian Crizotinib. Mengingat tingginya angka kejadian dan kematian akibat kanker paru, diperlukan modalitas baru dalam penanganan adenokarsinoma paru yang efektif dan menimbulkan efek samping seminimal mungkin pada pasien. ${ }^{11,12,13}$

\section{Metode}

Metode penyusunan artikel yang digunakan adalah literature review di mana data diperoleh dari literatur yang relevan pada database ilmiah yakni Pubmed dan Google Scholar. Literatur kemudian disaring menggunakan kriteria inklusi meliputi jurnal yang mengandung kata kunci "ARLAC ASO1316", "lung adenocarcinoma”, "PAMAM Dendrimer Generasi 4", dan "anti SFTPB antibody" dengan jangka waktu publikasi maksimal sepuluh tahun terakhir. Sementara kriteria eksklusi adalah literatur yang hanya dapat diakses bagian abstraknya. Berdasarkan kriteria inklusi dan eksklusi didapat 29 artikel yang relevan untuk dijadikan referensi dalam penulisan karya ini.

\section{Hasil}

\section{Protein ADP-Ribosylation Factor Like 4C (ARL4C) dan Peranannya dalam Adenokarsinoma Paru}

ADP-Ribosylation Factor Like 4C (ARL4C) adalah protein yang beperanan dalam proses morfogenesis epitel tubular, ekspresi gen inflamasi, dan metabolisme lemak, serta pengaturan mikrotubulus untuk modulasi transcellular vesicular transport. ${ }^{13}$ Protein ini juga memiliki peranan penting dalam proliferasi dan migrasi sel, di mana pengaktivan $A R L 4 C$ oleh jalur $W n t / \beta$-catenin atau $R A S / M A P K$ akan mengaktifkan RAS-related $C 3$ botulinum toxin substrate (RAC) dan menghambat RAS homolog family member (RHO). Proses ini akan diikuti oleh translokasi dari Yes-associated protein $(Y A P)$ dan transkripsi dari coactivator with PDZ-binding motif (TAZ) yang akan menstimulasi proliferasi dan migrasi sel. ${ }^{11,14,15}$

Protein ARL4C sendiri diasosiasikan dengan proses tumorgenesis pada jaringan kolorektal, hati, dan paru-paru. Penelitian juga menunjukkan bahwa ekspresi dari ARL4C 
secara spesifik diekspresikan oleh sel kanker paru sementara sel-sel normal di sekitar jaringan kanker tidak mengekspresikan ARL4C (Gambar 1a). Apabila dibandingkan dengan jaringan kanker kolorektal, ekspresi dari ARL4C lebih banyak terjadi pada jaringan kanker paru (Gambar 1b). ${ }^{14}$
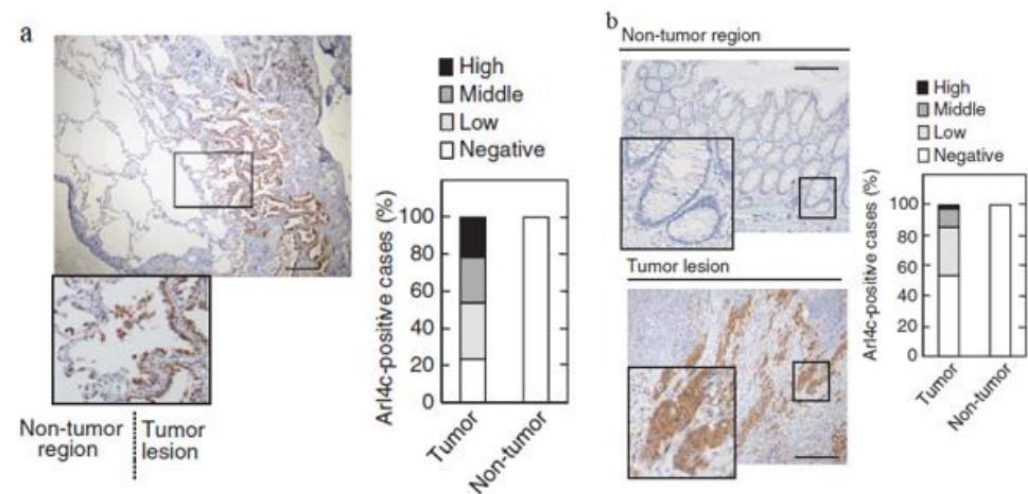

Gambar 1. ARLAC Diekspresikan pada Kanker Paru dan Kolorektal Manusia. ${ }^{14}$
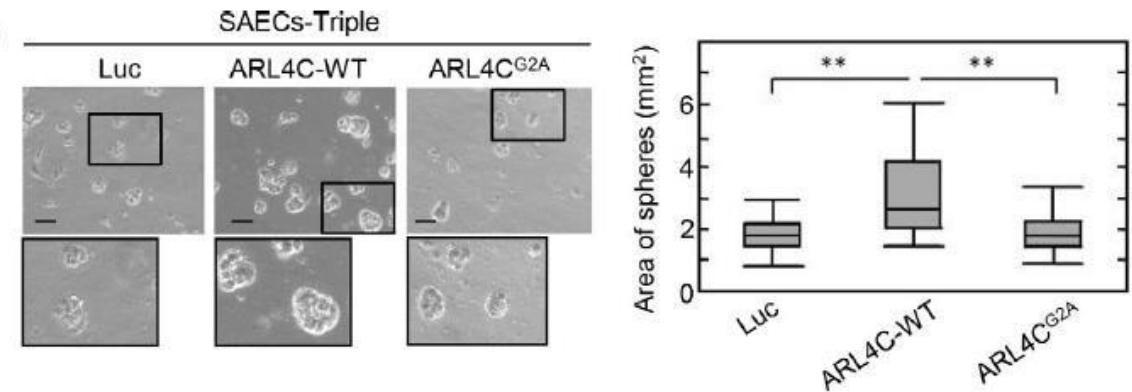

Gambar 2. Ekspresi ARL4C Memicu Pembelahan pada Sel SAEC Manusia. ${ }^{11}$
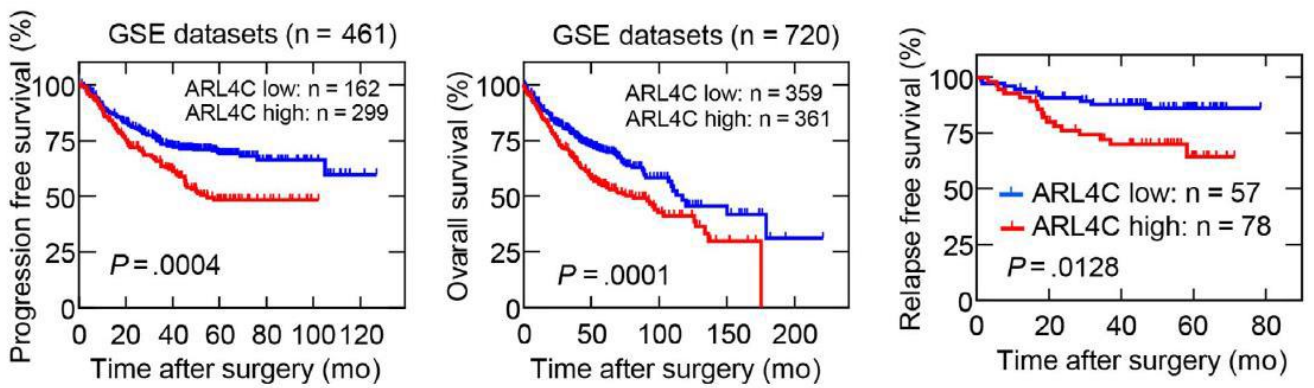

Gambar 3. Tingginya Kadar ARLAC pada Pasien Adenokarsinoma Paru Menurunkan Tingkat

Progression Free Survival, Overall Survival, dan Relapse Free Survival Pasien. ${ }^{11}$

Penelitian lebih lanjut menggunakan Small airway epithelial cell (SAEC) manusia menunjukkan bahwa mutasi pada gen protein ARL4C menyebabkan sel SAEC dalam 3D matrigel tidak dapat membelah, hal ini dapat dilihat dengan adanya penurunan luas koloni yang terbentuk, sehingga dapat disimpulkan bahwa protein ARL4C memegang peranan penting dalam pembelahan sel (Gambar 2). ${ }^{11}$

Selain itu penelitian secara klinis pada pasien adenokarsinoma paru menunjukkan adanya penurunan yang bermakna dari progression free survival rate, overall survival, dan relapse free survival pada pasien dengan kadar ARL4C sel kanker yang lebih tinggi (Gambar 3). Analisis multivariat juga menunjukkan kadar ekspresi ARL4C dan ukuran tumor $>2 \mathrm{~cm}$ merupakan faktor pemberat independen (Tabel 1), sehingga dapat ditarik kesimpulan bahwa tingginya kadar ekspresi dari ARL4C pada adenokarsinoma berkorelasi dengan tingkat agresivitas pada adenokarsinoma paru. ${ }^{11}$ 
Tabel 1. Analisis Multrivariat dari Relapse Free Survival Menggunakan Cox's Proportional Hazard Model. ${ }^{11}$

\begin{tabular}{llll}
\hline \multicolumn{1}{c}{ Parameter } & $\begin{array}{c}\text { Hazard } \\
\text { Ratio }\end{array}$ & $\begin{array}{c}\text { 95\% } \\
\text { Cl }\end{array}$ & P-value \\
\hline $\begin{array}{l}\text { Multivariate } \\
\text { analysis }\end{array}$ & & & \\
$\begin{array}{l}\text { ARL4C high vs } \\
\text { low expression }\end{array}$ & 2.30 & $1.06-$ & 0.0341 \\
Tumor size $(\geq$ & & 5.22 & \\
$\begin{array}{l}2.0 \text { vs }<2.0) \\
(\mathrm{cm})\end{array}$ & 4.52 & $1.73-$ & 0.0012 \\
\hline
\end{tabular}

\section{Potensi ADP-Ribosylation Factor Like 4C Antisense Oligonucleotide-1316 (ARLAC ASO-1316)}

\section{Antisense Oligonucleotide}

(ASO) merupakan oligodeoksinukleotida untai tunggal pendek, sintetis yang dapat mengubah mRNA gen target sesuai dengan pasangan WatsonCrick kemudian mengurangi, memulihkan, atau memodifikasi ekspresi protein melalui beberapa mekanisme berbeda. Penggunaan ASO dalam terapi manusia menawarkan keuntungan karena dapat secara spesifik menghambat gen target, dalam hal ini gen protein ARL4C. Pada penelitian ini, ASO dikombinasikan dengan Amidobridge Nucleic Acid (AmNA), yang merupakan nukleotida RNA yang dimodifikasi serupa Locked Nucleic Acid sehingga telah dialterasi untuk mengurangi konformasi isomer. Ciri khas AmNA adalah mempunyai gugus amida yang mampu mempertemukan karbon 2' dan 4' dalam ribosanya. Keuntungan AmNA adalah memiliki ketahanan yang tinggi terhadap nuklease, meningkatkan spesifisitas target, dan dapat membentuk struktur heliks ganda yang sangat stabil. ${ }^{16,17}$

Penelitian secara in vitro menggunakan sel adenokarsinoma paru dengan mutasi KRAS yakni galur A549 dan sel adenokarsinoma paru dengan mutasi EGFR yakni galur H1975 menunjukkan galur H1975 merupakan galur yang paling sering menunjukkan resistensi terhadap generasi pertama EGFR-TKI. Penelitian menunjukkan pula bahwa pemberian ARL4C ASO menurunkan ekspresi protein ARL4C pada kedua jenis sel ini. Sel A549 dan
H1975 yang sebelumnya mengekspresikan GFP atau ARL4C-GFP secara stabil ditransfeksi dengan ARL4C ASO-1316 kemudian diamati. Dapat disimpulkan bahwa ARL4C ASO-1316 menghambat ekspresi ARL4C endogen pada kedua tipe sel adenokarsinoma ini lebih baik dibanding kontrol ASO (Gambar 5 Lampiran A). ${ }^{11}$

Sel adenokarsinoma paru A549 dan H1975 kemudian ditransfeksi kembali dengan kontrol ASO atau ARL4C ASO-1316 selanjutnya dikultur dalam 3D matrigel selama lima hari untuk sel A549 dan empat hari untuk H1975. Data yang didapat menunjukkan bahwa ARL4C ASO-1316 mengurangi luas wilayah koloni dari sel A549/GFP dan sel H1975/GFP secara signifikan (Gambar 6 Lampiran A). Hal ini menunjukkan bahwa pemberian ARL4C ASO1316 dapat mencegah proliferasi dari sel kanker A549 dan H1975. Selain menghambat proliferasi, pemberian ARL4C ASO-1316 juga menekan migrasi sel A549 dan H1975 yang ditunjukkan dari pengurangan angka relative migration yang didapat pada eksperimen dengan menggunakan teknik migration assay (Gambar 7 Lampiran A). ${ }^{11}$

Selain telah teruji secara in vitro, potensi ARL4C ASO-1316 juga telah teruji pada tahap in vivo. Percobaan dilakukan pada mencit dengan menggunakan teknik orthotopic lung tumor, yakni teknik menanamkan sel tumor ke dalam paru-paru mencit, yang lebih baik dibandingkan dengan teknik subcutaneous xenograft model untuk menguji karakteristik dari calon pengobatan baru untuk kanker paru. ${ }^{11}$

Dengan menggunakan teknik orthotopic lung tumor, sel adenokarsinoma paru A549 kemudian ditransplantasikan ke paru-paru mencit dan didiamkan selama tujuh hari. Pada hari ke-7, 11, dan 15 dilakukan pemberian ARL4C ASO-1316 secara intratracheal pada kelompok eksperimen sementara pada kelompok kontrol tidak diberikan ARL4C ASO1316. Pada hari ke-7 dan hari ke-21 gambar intensitas bioluminescence pada jaringan tumor dari kedua kelompok diambil dan dicek untuk dilihat perbandingannya. Pada hari ke-21 dilakukan pembedahan untuk melihat perkembangan dari sel tumor pada kedua kelompok mencit. Jaringan hasil pembedahan kemudian diwarnai dengan menggunakan anti- 
ARL4C dan anti-Ki 57 antibody, sel dengan Ki67 positif kemudian dihitung untuk dilihat perbandingan jumlah di antara kedua kelompok (Gambar 8 Lampiran A). ${ }^{11}$

Prosedur yang sama dilakukan pula pada sel adenokarsinoma paru H1975 ketika sel ini ditransplantasikan dengan menggunakan teknik orthotopic lung tumor kemudian pada hari ke-7, 9 dan 11 dilakukan pemberian ARL4C ASO1316 secara intratracheal pada kelompok eksperimen serta dilakukan pengambilan gambar intensitas bioluminescence dari tumor pada kedua kelompok di hari ke-7 dan hari ke14. Pembedahan dilakukan di hari ke-14 untuk membandingkan ukuran sel tumor pada kedua kelompok serta melakukan pengecatan antiARL4C dan anti $\mathrm{Ki} 57$ antibody serta penghitungan sel dengan Ki-67 positif pada kedua kelompok (Gambar 9 Lampiran A). ${ }^{11}$

Dari percobaan secara in vivo dapat dilihat bahwa pemberian ARL4C ASO-1316 dapat mencegah pembentukan tumor yang diinduksi dari sel kanker paru A549 dan H1975 dengan menggunakan teknik orthoropic lung tumor. Kelebihan lainnya dari penggunaan ARL4C ASO-1316 adalah kemampuannya untuk tidak memicu resistensi lanjutan dari sel kanker karena mekanisme yang digunakan pada ARL4C ASO-1316 berbeda dengan mekanisme yang dipakai oleh obat EGFR TKI. Hal ini menunjukkan bahwa ARL4C ASO-1316 yang diberikan secara intratracheal memiliki potensi sebagai pengobatan baru kanker paru. ${ }^{11}$

Meskipun demikian, pemberian obat secara intratracheal pada manusia dinilai invasif dan tidak nyaman bagi pasien sehingga administrasi dari ARL4C ASO-1316 harus dilakukan melalui jalur lain. Di sisi lain, sebagian besar dosis dari ARL4C ASO-1316 terendap secara subselular sehingga diperlukan sebuah carier yang dapat meningkatkan bioavailabilitas dari ARL4C ASO-1316 ini.

\section{Potensi Polyamidoamine Dendrimer Generasi 4-Anti Surfactant protein B}

Polyamidoamine Dendrimer merupakan struktur unik bercabang yang terdiri dari tiga bagian yakni Core, hyperbranched mantle, dan corona. PAMAM Dendrimer Generasi 4 berarti PAMAM Dendrimer ini memiliki 4 cabang dari inti di luar lapisan terluarnya (Gambar 10 Lampiran B). ${ }^{11,18}$

Keunggulan PAMAM Dendrimer adalah dengan struktur amine terminated yang dimiliki olehnya dapat dimodifikasi sesuai dengan kadar pH lingkungan. Apabila dimasukan ke dalam lingkungan yang kaya dengan modalitas dan dalam suasana $\mathrm{pH}$ yang sedikit basa maka struktur PAMAM Dendrimer akan memadat sehingga memungkinkan modalitas untuk berikatan dengan cabang-cabang dan terperangkap di sela cabang. Sebaliknya, apabila berada di lingkungan yang sedikit asam struktur PAMAM Dendrimer akan melebar sehingga memungkinkan modalitas yang dibawa oleh PAMAM Dendrimer untuk keluar dan bereaksi dengan lingkungan. Hal ini menjadi sangat menguntungkan terutama dalam pengobatan kanker karena jaringan kanker sendiri memiliki lingkungan yang $\mathrm{pHnya}$ sedikit asam (Gambar 11 Lampiran B). ${ }^{18,19}$

Selain dari struktur, PAMAM Dendrimer apabila diadministrasikan secara intravena dapat mengalami fenomena Enhanced Permeability and Retention Effect (EPR effect), fenomena ketika PAMAM Dendrimer terakumulasi secara khusus pada jaringan kanker. Hal ini dapat terjadi karena sel kanker juga mensekresikan vasodilator dan juga memicu angiogenesis sehingga akumulasi PAMAM Dendrimer dapat terjadi. Hal ini tentu sangat menguntungkan dalam penghantaran modalitas. Selain itu, jalur intravena sendiri memberikan beberapa keuntungan seperti meningkatkan ketersediaan obat sebab penghantaran obat berlangsung dengan cepat, dosis terapi dapat diberikan secara maksimal, dan dapat dipertahankan atau dimodifikasi dengan mudah (Gambar 12 Lampiran B). ${ }^{18,19}$

Penelitian telah membuktikan bahwa dengan menggunakan PAMAM Dendrimer dapat memperbanyak muatan dari obat cisplatin sehingga dapat mempermudah dan mengefisienkan pemberian obat pada pasien dengan kanker paru (Tabel 2 Lampiran B). ${ }^{20}$

Untuk meningkatkan akurasi dari penggunaan PAMAM dendrimer maka dapat ditambahkan Surfactant protein B (SFTPB) yang merupakan salah satu protein yang diketahui mengalami peningkatan kadar pada penderita NSCLC jika dibandingkan dengan 
orang normal. ${ }^{21,22}$ Protein ini sendiri diekspresikan spesifik pada jaringan paru-paru sehingga pada pewarnaan dengan anti-SFTPB derivate. Pada kanker jaringan lain seperti kanker kolorektal, kanker payudara, dan kanker prostat tidak ditemukan adanya protein ini dalam kanker jaringan lain (Gambar 13 Lampiran B). ${ }^{23}$ Penggabungan antara PAMAM Dendrimer dan SFTPB dapat dilakukan dengan teknik konjugasi sehingga protein SFTPB akan berada di permukaan PAMAM Dendrimer Generasi 4. ${ }^{24}$

\section{Mekanisme Konstruksi ARL4C ASO-1316 dan PAMAM Dendrimer G4-anti SFTPB antibody}

Mekanisme konstruksi ARL4C ASO-1316 dimulai dengan sintesis Amidobridge Nucleic Acid (AmNA) yaitu saat senyawa 1 mengalami proses trifilasi dan dilanjutkan reaksi $\mathrm{S}_{\mathrm{N}} 2$ dan $\mathrm{NAN}_{3}$ sehingga terbentuk senyawa 3 . Dengan menggunakan tributylammonium fluoride, gugus silyl yang memproteksi senyawa 3 kemudian dipisahkan sehingga menghasilkan senyawa 4. Senyawa 4 yang memiliki bagian gugus free hydroxyl akan dioksidasi oleh pyridium dichromate dalam dimethylformamide untuk selanjutnya menghasilkan asam alkanoat pada senyawa 5. Gugus anion azida yang berada pada 2' ditransmutasikan menjadi gugus amino melewati reaksi staudinger (penambahan $\mathrm{PBu}_{3}$ di dalam tetrahydrofuran pada senyawa 5) yang kemudian memproduksi senyawa $6{ }^{25}$

Reaksi konsensasi dari 1-Ethyl-3-(3dimethylaminopropyl)carbodiimide akan mencetuskan terhubungnya gugus alkanoat atau karboksilat yang terletak pada 4' serta gugus amino yang berposisi di 2' agar memproduksi senyawa 7. Senyawa 7 tersebut kemudian terdebenzilasi bersama catalytic hydrogenolysis sehingga menghasilkan monomer 8 bergugus fungsi karbonil. ${ }^{25}$

Gugus nitrogen fungsional yang terletak pada 2' memungkinkan terjadinya sintesis beberapa jenis turunan molekul identik $\mathrm{N}$ subtituted setelah monomer yang diinginkan dengan gugus karbonil berhasil disintesis. Pembentukan proteksi oleh benzyloxymethyl pada timin bertujuan agar tidak terjadi $\mathrm{N}$ metilasi. Debenzilasi oleh hidrogenolisis katalik terjadi setelah $\mathrm{N}$-metilasi pada gugus fungsi nitrogen sehingga terproduksi N-metilasi dari monomer 10. Untuk membentuk oligonuklotida hidroksi dari monomer 8 dan 10, 4,4'dimethoxytrityl chloride kemudian mentrilasi secara elektif hidroksi primer dari masingmasing monomer 8 dan 10. Gugus hidroksi sekunder bersama $\mathrm{H}$-fosfonat melibatkan praaktivasinya sebagai anhidrida campuran dengan pivaloyl klorida dan diikuti oleh oksidasi dengan yodium dalam wet-piridin dengan 2-Cyanoethyl $N, \quad N, \quad N^{\prime}, \quad N^{\prime}-$ tetraisopropylphosphorodiamidite agar dapat berakhir menjadi fosforamidit timin 9 dan 12 . Dalam pengubahan bagian timin menjadi sitosin, gugus secondary hydroxy dari nukleosida tertritilasi 11 akan diproteksi oleh gugus triethylsilyl. Nukleosida tertritilasi 11 kemudian dicampurkan bersama 2,4,6triisopropylbenzenesulfonyl chloride yang mengandung 4-dimethylaminopyridine dan triethylamine yang selanjutnya akan mensulfonasi gugus 4-okso kelompok timin. ${ }^{25}$

Nukleotida tanpa gugus fosfat tersebut tersulfonasi diganti dengan amonia untuk menghasilkan turunan 5-methylcytidine. Komponen amino eksosiklik 5-methylcytidine diproteksi dengan gugus asetil, diikuti desilasi dan penambahan gugus fosfat secondary hydroxyl group dengan 2-cyanoehyl-N, N, N', $\mathrm{N}$-tetraisopropylphosphordiamidite agar mampu menghasilkan 5-methylcytidine phosphordiamidite, serta diproteksi N4-acetyl sehingga terbentuklah sebuah molekul identik AmNA (Gambar 4). ${ }^{25}$ Monomer AmNA tersebut kemudian diinkorporsikan ke antisense oligonucleotide spesifik protein ARL4C yang telah tersedia sehingga terbentuklah ARL4C.

PAMAM Dendrimer dikonstruksi dengan metode divergent di mana pembentukannya dimulai dengan penambahan EDA ke inti dendrimer bercabang keluar menghasilkan generasi dendrimer 4. PAMAM Dendrimer yang telah dibentuk akan dikonjugasikan dengan antiSFTPB antibody sehingga permukaan PAMAM Dendrimer akan terdapat protein anti-SFTPB antibody. ${ }^{24,26,27}$ Perlakuan selanjutnya dilakukan dalam larutan HEPES buffer (pH 7.4) di mana PAMAM G4-Anti SFTPB yang telah terbentuk dicampurkan dengan ARL4C ASO-1316 dan diinkubasi pada suhu ruang selama satu jam. ${ }^{28}$ 


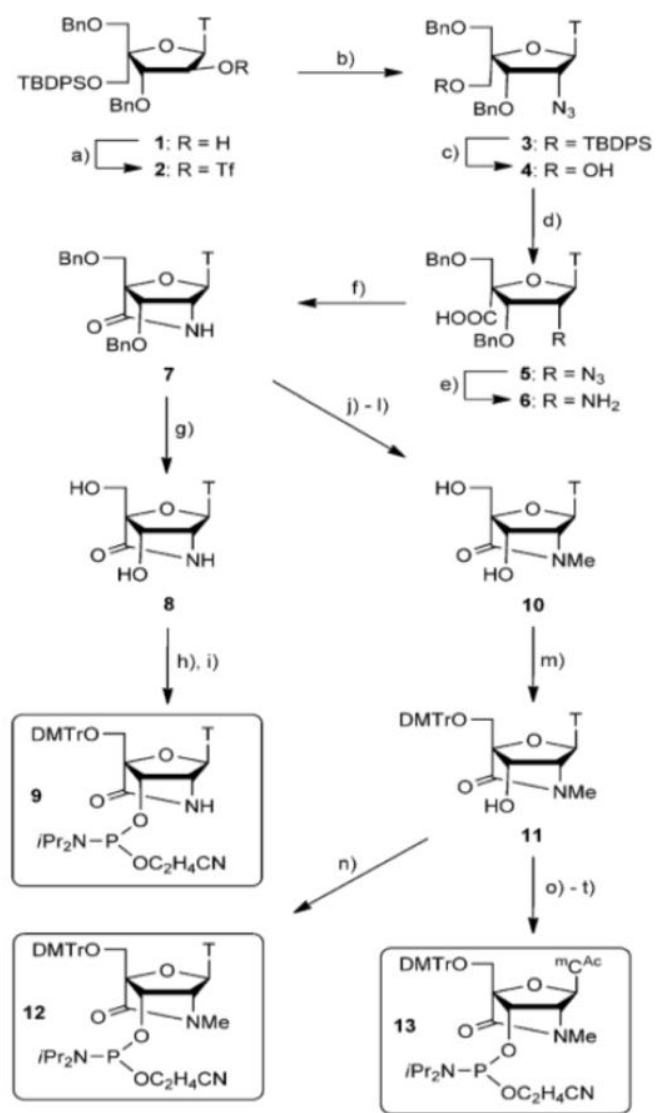

Gambar 4. Proses Sintesis AmNA. ${ }^{25}$

\section{Jalur Administrasi serta Mekanisme Kerja ARL4C ASO-1316 dan PAMAM Dendrimer G4-anti SFTPB antibody}

Jalur administrasi yang dipilih untuk modalitas ARL4C ASO-1316 dengan PAMAM Dendrimer G4-Anti SFTPB adalah jalur intravena karena menggunakan jalur ini mampu memberikan efek terapeutik yang dapat segera tercapai sebab pengantaran obat berlangsung cepat, absorbsi obat secara total, dan kemudahan untuk mengontrol efek terapeutik. ${ }^{18,19}$

PAMAM Dendrimer G4-Anti SFTPB kemudian akan mengalami fenomena Enhanced Permeability and Retention Effect (EPR effect), fenomena ketika PAMAM Dendrimer terakumulasi secara khusus pada jaringan kanker. Hal ini dapat terjadi karena sel kanker juga mensekresikan vasodilator dan juga memicu angiogenesis sehingga akumulasi PAMAM Dendrimer G4-Anti SFTPB dapat terjadi. Ketika terakumulasi pada jaringan kanker yang pHnya sedikit asam, PAMAM Dendrimer G4-Anti SFTPB akan melebar sehingga memungkinkan ARL4C ASO-1316 yang dibawa oleh PAMAM Dendrimer G4-Anti $S F T P B$ untuk keluar dan bereaksi dengan jaringan tumor. ${ }^{18,19}$

Modifikasi RNA adalah mekanisme di mana ARL4C ASO-1316 dapat berfungsi. Berlangsung di dalam nukleus, ARL4C ASO1316 akan berpasangan dengan mRNA kanker paru tetapi, mengingat desainnya, tidak akan memulai degradasi langsung mRNA. Sebagai gantinya, ARL4C ASO-1316 memodifikasi mRNA pada situs poliadenilasi untuk mencegah terjemahan mRNA atau mengubah stabilitas RNA, sehingga menurunkan mRNA dan protein yang dimaksud tanpa degradasi. Selain itu, penggunaan ARL4C ASO-1316 pemodifikasi RNA yang sangat efektif dalam mengubah pola penyambungan mRNA alternatif. Pengikatan ARL4C ASO-1316 ke persimpangan intron/ekson dapat memengaruhi pembentukan dan pengikatan faktor penyambungan atau mengacaukan bagian penyambungan. Jalur semacam itu mungkin paling bermanfaat untuk gangguan dengan cacat penyambungan yang diketahui untuk memulihkan fungsi protein atau untuk mengeksklusi bentangan DNA yang bermutasi. ${ }^{29}$

\section{Kesimpulan}

Kemampuan ARL4C ASO-1316 untuk menghambat pembelahan dan migrasi dari sel adenokarsinoma paru baik secara in vivo maupun in vitro memberikan harapan mengenai modalitas baru dalam pengobatan adenokarsinoma paru. Dengan menambahkan carrier PAMAM Dendrimer G4-Anti SFTPB yang memiliki kemampuan lebih untuk menghantarkan modalitas, ARL4C ASO-1316 dapat mencapai jaringan target lebih cepat sehingga memberikan efek lebih maksimal dalam pengobatan adenokarsinoma paru.

Untuk selanjutnya diperlukan penelitian terkait dosis yang efektif model terapi ini. Selain itu, diperlukan juga penelitian secara in vivo, in vitro, dan uji klinis terkait efektivitas, dan efek samping yang dapat timbul dari terapi ini sehingga di masa depan dapat digunakan oleh masyarakat untuk mengurangi angka mortalitas akibat adenokarsinoma paru baik di Indonesia maupun di dunia. 


\section{Ucapan Terima Kasih}

Terima kasih kepada pihak jurnal JEKK karena telah mengijinkan kami menggunakan template yang mereka miliki.

\section{Daftar Pustaka}

1. European Respiratory Society. 2017. The Global Impact of Respiratory DiseaseSecond Edition. Forum of International Respiratory Societies ; 5-42 p. Available from:https://www.who.int/news-room/factsheets/detail/cancer.

2. World Health Organization. 2020. Cancer. [Internet]. Who.int. [cited 15 September 2020] Available from https://www.who.int/news-room/factsheets/detail/cancer.

3. World Health Organization. 2019. Indonesia Source GLOBOCAN 2018. Int Agency Res Cancer [Internet]; 256:1-2. Available from: http://gco.iarc.fr.

4. Hin HS. 2013. Dealing with lung cancer complication : How aggresice can we be ?. Malysian Thoracic Society ;1-23.

5. Kementerian Kesehatan RI. 2018. Pedoman Pengendalian Risiko Kanker Paru ;1-13.

6. Komite Penanggulangan Kanker Nasional. 2017. Panduan Penatalaksanaan Kanker Paru ; 1-10.

7. American Cancer Society. 2019. What is Lung Cancer? [Internet]. Cancer.org. [cited 15 September 2020]. Available from : https://www.cancer.org/ cancer/ lungcancer /about /what-is.html.

8. Myers, David J; Wallen, Jason M. 2020. Cancer, Lung Adenocarcinome [Internet]. NCBI. [cited 15 September 2020]. Available from : $\mathrm{https://}$ www.ncbi.nlm.nih.gov/ books/ NBK519578.
9. Cruz, Charles S. Dela; Tanoue, Lynn T ; Matthay RA. 2013. Lung Cancer : Epidemiology, Etiology and Prevention. 32(4):11.

10. Zamay TN, Zamay GS, Kolovskaya OS, Zukov RA, Petrova MM, Gargaun A, et al. 2017. Current and prospective protein biomarkers of lung cancer. Cancers (Basel). 9(11):1-22.

11. Kimura K, Matsumoto S, Harada T, Morii E, Nagatomo I, Shintani Y, et al. 2020. ARL4C is associated with initiation and progression of lung adenokarsinoma and represents a therapeutic target. Cancer Sci.111(3):951-61.

12. Amararathna M, Goralski K, Hoskin D, Rupasinghe HP. 2019. Pulmonary NanoDrug Delivery Systems for Lung Cancer: Current Knowledge and Prospects. J Lung Heal Dis. 3(2):11-28.

13. Sun Y, Zhang Z, Xiang F, Zhang M, Chen Q, Tang L, et al. 2020. Decreasing Arl4c expression by inhibition of AKT signal in human lung adenokarsinoma cells. Life Sci [Internet]; $246 \quad$ (February):117428. Available from: https://doi.org/ 10.1016/ j.lfs.2020.117428.

14. Fujii S, Matsumoto S, Nojima S, Morii, E, Kikuchi A. 2015. Arl4c expression in colorectal and lung cancers promotes tumorigenesis and may represent a novel therapeutic target. Oncogene. 34, 48344844.

15. Matsumoto S, Fujii S, Sato A, Ibuka S, Kagawa Y, Ishii M, et al. 2014. A combination of Wnt and growth factor signaling induces Arl4c expression to form epithelial tubular structures. EMBO J.33(7):702-18. 
16. Uehara T, Choong C, Nakamori M. et al. 2019. Amido-bridged nucleic acid (AmNA)-modified antisense oligonucleotides targeting $\alpha$-synuclein as a novel therapy for Parkinson's disease. Sci Rep 9, 7567. Available from: https://doi.org/ 10.1038/s41598-01943772-9.

17. Yamamoto T, Yahara A, Waki R, Yasuhara H, Wada F, Harada-Shiba M, Obika S. 2015. Amido-bridged nucleic acids with small hydrophobic residues enhance hepatic tropism of antisense oligonucleotides in vivo. Organic \& Biomolecular Chemistry. 13(12), 37573765.

18. Kesharwani P, Iyer AK. 2015. Recent advances in dendrimer-based nanovectors for tumor-targeted drug and gene delivery. Drug Discov Today. 20(5):536-47. Available from:http://dx.doi.org/ 10.1016/ j.drudis.2014.12. 012.

19. Sandoval-Yañez C, Rodriguez CC. 2020. Dendrimers: Amazing platforms for bioactive molecule delivery systems. Materials (Basel). 13(3):1-20.

20. Nguyen H, Nguyen NH, Tran NQ, Nguyen CK. 2015. Improved method for preparing cisplatin-dendrimer nanocomplex and its behavior against NCI-H460 lung cancer cell. J Nanosci Nanotechnol. 15(6):410610.

21. Sin D, Tammemagi CM, Lam S, Barnett MJ, Duan X, Tam A, et al. 2013. Prosurfactant protein $\mathrm{B}$ as a biomarker for lung cancer prediction. J Clin Oncol. 31(36): 4536-43.

22. He Y, Jiang Z, Tong F, Li M, Yin X, Hu S, et al. 2017. Experimental study of peripheral-blood pro-surfactant protein $\mathrm{B}$ for screening non-small cell lung cancer. Acta Cir Bras. 32(7):568-75.
23. The Human Protein Atlas. 2019. SFTPB [Internet]. Proteinatlas.org. [Cited 15 September 2020]. Available from : https://www.proteinatlas.org/ ENSG 00000 168878-SFTPB/pathology.

24. Amreddy N, Babu A, Panneerselvam J, Srivastava A, Muralidharan R, Chen A, et al. 2018. Chemo-biologic combinatorial drug delivery using folate receptor-targeted dendrimer nanoparticles for lung cancer treatment. Nanomedicine Nanotechnology, Biol Med. 14(2):373-84. Available from: https://doi.org/10.1016/j.nano.2017.11.010

25. Yahara A, Shrestha AR, Yamamoto T, Hari Y, Osawa T, Yamaguchi M, et al. 2012. Amido-Bridged Nucleic Acids (AmNAs): Synthesis, Duplex Stability, Nuclease Resistance, and in Vitro Antisense Potency. ChemBioChem. 13(17):2513-6.

26. Peterson J, Ebber A, Allikmaa V, Lopp M. 2010. Synthesis And Cze Analysis Of Pamam Dendrimers With an Ethylenediamine Core. Proceedings of the Estonian Academy of Sciences, Chemistry.50(3):156-166.

27. Ziemba B, Matuszko G, Bryszewska M, Klajnert B. 2012. Influence of dendrimers on red blood cells. Cellular and Molecular Biology Letters. 17(1).

28. Nourazarian A, Najar A, Farajnia S, Khosroushahi A, Pashaei-Asl R, Omidi Y. 2012. Combined EGFR and c-Src Antisense Oligodeoxynucleotides Encapsulated with PAMAM Denderimers Inhibit HT-29 Colon Cancer Cell Proliferation. Asian Pacific Journal of Cancer Prevention. 13(9):4751-4756. 
29. Mallory A. Havens, Michelle L. Hastings. Spliceswitching antisense oligonucleotides as therapeutic drugs, Nucleic Acids Research, Volume 44, Issue 14, 19 August 2016, Pages 6549-6563. Available from: https://doi.org/10.1093/nar/gkw533Tavel, P. 2007. Modeling and Simulation Design. AK Peters Ltd., Natick, MA. 